\title{
HISTOCHEMICAL HETEROGENEITY OF SECRETORY STRUCTURES IN THE FLOWERS OF LYSIMACHIA NUMMULARIA L.
}

\author{
Radchenko Volodymyr, Likhanov Artyr*, Matyashuk Raisa
}

Institute for Evolutionary Ecology of the NAS of Ukraine, Kyiv, Ukraine

\section{ГІСТОХІМІЧНА ГЕТЕРОГЕННІСТЬ СЕКРЕТОРНИХ СТРУКТУР У KBITKAX LYSIMACHIA NUMMULARIA L.}

\author{
Радченко Володимир, Ліханов Артур, Матяшук Раїса \\ Received 11.5. 2017 \\ Revised 22. 5. 2017 \\ Published 29. 11. 2017
}

The study of flowers of Lysimachia nummularia L. showed that glandular trichomes are formed on the stamen filaments, as well as on the adaxial and abaxial surfaces of the sepals and petals. The polyfunctionality of trichomes in plants Lysimachia nummularia are based on the biochemical and anatomical heterogeneity of cells and secretory structures, which are a functional component of the ecological plasticity of the species. Accumulation of phenolic compounds in the tissues of leaves, stems and flowers begins at the early stages of plant development. Secondary metabolites are localized in the cytoplasm of the cells of the upper and lower epidermis of the leaves, in the parenchyma of the stems of brephical plants. A significant amount of condensed polyphenolic compounds are found in cells of the parenchyma of the receptacle, the integumentary tapetum and the epidermis of the petals in the surrounding polysaccharides. They act as a chemical barrier, which slows down the oxidation of phenols. A significant number of pectins and glycans were found in the cells of the glandular trichomes. A certain spatial uneven distribution of polysaccharides in the external secretory structures is established. It is shown that they are concentrated in the basal cells of the legs and are almost completely absent in cells that are directly linked to the secretory head. Their cell walls are thin and almost completely formed by pectins. This creates the prerequisites for easy head breaking along with secretory fillers. Under such conditions, when they are harvested by bees, the risk of premature leakage, oxidation and polymerization of biologically active compounds is reduced. Polysaccharides in the cells of the secretory epithelium can be considered as the basis for the creation of a biopolymer film with bactericidal and fungicidal components that use bees when facing cell nests. It was found out that the cell components of the trichome head are capable of intense autofluorescence in blue, blue-green and green spectrums. The expressed structural and biochemical heterogeneity of micromorphological elements of the secretory system of plants Lysimachia nummularia is physiologically and ecologically related to their functions. In our opinion, these functions can be much more complicated than it was thought up to this day. Among these, their direct or indirect participation in the work of systems of extracellular and long-distance signaling, regulation of forage and nesting behavior of insects cannot be excluded.

Keywords: Idioblast; Lysimachia nummularia L;. phenols; polysaccharides; stamens; trichomes

\footnotetext{
*Corresponding author: Artyr Likhanov, Institute for Evolutionary Ecology of the NAS of Ukraine, Kyiv,
} Ukraine, $\bowtie$ likhanov.bio@gmail.com 


\section{Вступ}

Унікальний біохімічний складсекреторнихструктур рослин роду LysimachiaL.єджереломенергіï, незамінних поживних речовин і будівельних матеріалів, які потрібні для вузьких оліголектів роду Macropis Panzer (Радченко и Песенко, 1994). Біохімічний склад виділень секреторних структур квіток має виняткове значення для комах-запилювачів, які використовують ці речовини для облицювання стінок комірок.

Відомо, що у квітках і секреторних клітинах головчастих трихом рослин роду Lysimachia окрім флоральних ліпідів (Buchmann, 1987), накопичуються амінокислоти, каротиноїди, флавоноїди (Toth, 2012); пальмітинова, міристинова, лінолева, інші кислоти; борнеол, бензофенон, гексадекан, метилевганол (Демид, 2014); терпеноїди і тритерпенові сапоніни (Podolak, 2013). Ліпіди квіток Lysimachia аналогічні тим, що виробляються залозою Дюфура у інших видів бджіл. Бджоли використовують багатокомпонентну суміш продуктів секреції епітелію трихом Lysimachia, які окрім рослинних олій, містять органічні сполуки, що мають фунгіцидні та антибіотичні властивості. Саме така речовина використовується бджолами роду Мacropis для облицювання комірок їх гнізд, що будуються у ґрунті. Питання використання бджолами продуктів рослинного походження як будівельного матеріалу з антисептичними властивостями $\epsilon$ надзвичайно складним і водночас цілком практичним, тому заслуговує на увагу та потребує детального вивчення. Метою нашої роботи було дослідження гістохімічної гетерогенності секреторних структур Lysimachia nummularia L. в аспекті їх значення у взаємодіях із комахами-запилювачами.

\section{Матеріали та методи}

Дослідження проводили на рослинах Lysimachia nummularia, які збирали протягом 2014 2016 рр. у лісопаркових насадженнях м. Києва. Гістохімічні дослідження секреторних структур проводили на постійних мікропрепаратах $(7-8 \mu \mathrm{m})$ поперечних і поздовжніх зрізів генеративних органів рослин. Якісне визначення вторинних метаболітів, полісахаридів, білків у тканинах виконували за стандартними прописами (Фурст, 1979; Pellicciari and Biggiogera, 2017). Фотодокументацію і обробку отриманих даних виконували в спеціалізованій програмі для аналізу цифрових зображень - Image-Pro Premier 9.0.

\section{Результати та їх обговорення}

В умовах Київського Полісся більшість рослин Lysimachia nummularia має низький генеративний потенціал і тому популяції даного виду часто представлені вегетативними клонами. Типовим для вербозілля $є$ гейтоногамія, коли запилення відбувається між квітками генетично однакових рослин. Перехресне запилення забезпечують бджоли, яких рослини приваблюють за допомогою специфічних атрактантів. Їх синтез відбувається у спеціальних клітинах членистоголовчастих трихом секреторного типу, що формуються на тичинкових нитках, а також на адаксіальній і абаксіальній поверхнях пелюсток й чашолистиків. Кількість трихом на одиницю площі $\epsilon$ мінливою ознакою, яка залежить від умов місцезростання рослин. У елементах квітки найбільше число трихом спостерігається на тичинкових нитках. Головчасті трихоми мають досить складну будову. Вони утворюються з епідермальних клітин. Після периклінального поділу базальна клітина ділиться ще раз або двічі, від чого формується дво- три-, іноді чотириклітинна ніжка. Верхня клітина ділиться антиклінально і утворює багатоклітинну головку трихома. Клітини ніжок трихом біля основи тичинкових ниток досить видовжені, а базальні й середні клітини вкриті товстим шаром кутикули. Поліфункціональність трихом у рослин Lysimachia nummularia ґрунтується на біохімічній та анатомічній гетерогенності клітин і секреторних структур, які $є$ функціональною складовою екологічної пластичності виду. Дана специфіка пов'язана із синтезом і локалізацією вторинних метаболітів, а також вільних жирних кислотіполісахаридів. Крімлетких речовин і олій, уквітках рослин Lysimachia nummularia 
синтезується і накопичується значна кількість фенольних сполук. За нашими даними, збільшення вмісту фенолів (кон'югатів оксикоричних кислот, флавоноїдів і конденсованих танінів), тритерпенових сапонінів та терпеноїдів у тканинах листків, стебел і квіток відбувається вже на початкових стадіях їх розвитку. Гістохімічні реакції дозволили виявити, що здебільшого вони локалізовані в цитоплазмі клітин верхнього і нижнього епідермісу. Перші клітини, що заповнюються поліфенольними сполуками (ідіобласти), виявляються в примордіях метамерів і в клітинах апікальної меристеми на відстані 180 - $250 \mu$ m від точки росту. У стеблах ювенільних пагонів і квітконіжок групи ідіобластів локалізуються серед клітин паренхіми вздовж провідних пучків (Figure 1, а-с). Слід також зазначити, що в секреторних клітинах виявлено високий вміст білків, які майже відсутні у клітинах-ніжках (Figure 1, i).

На особливу увагу заслуговує розподіл полісахаридів у структурах тканин генеративних органів. Нами визначено, що більшість нерозчинних у спиртах конденсованих поліфенольних сполук, що в значних кількостях містяться у клітинах паренхіми квітколожа, інтегументального тапетума та епідерміса пелюсток, оточені пектинами і зв'язаними з ними іншими полісахаридами (Figure 1, a, d, k). Після гідролізу пектиназою, клітини тканин зав'язі, насіннєвих зачатків і тичинок, що містили поліфенольні сполуки, більше не виявляли позитивної реакції на полісахариди. Отже, $\epsilon$ підстави вважати, що останні $\epsilon$ важливою складовою клітин-ідіобластів. Полісахариди огортають поліфеноли і формують капсулу, яка, вірогідно, виконує функцію хімічного бар'єра, що уповільнює процеси їх окиснювання. Значна кількість полісахаридів виявлена також у нерозчинній в спиртах фракції компонентів секреторних каналів (Figure 1, g, вказано стрілкою).

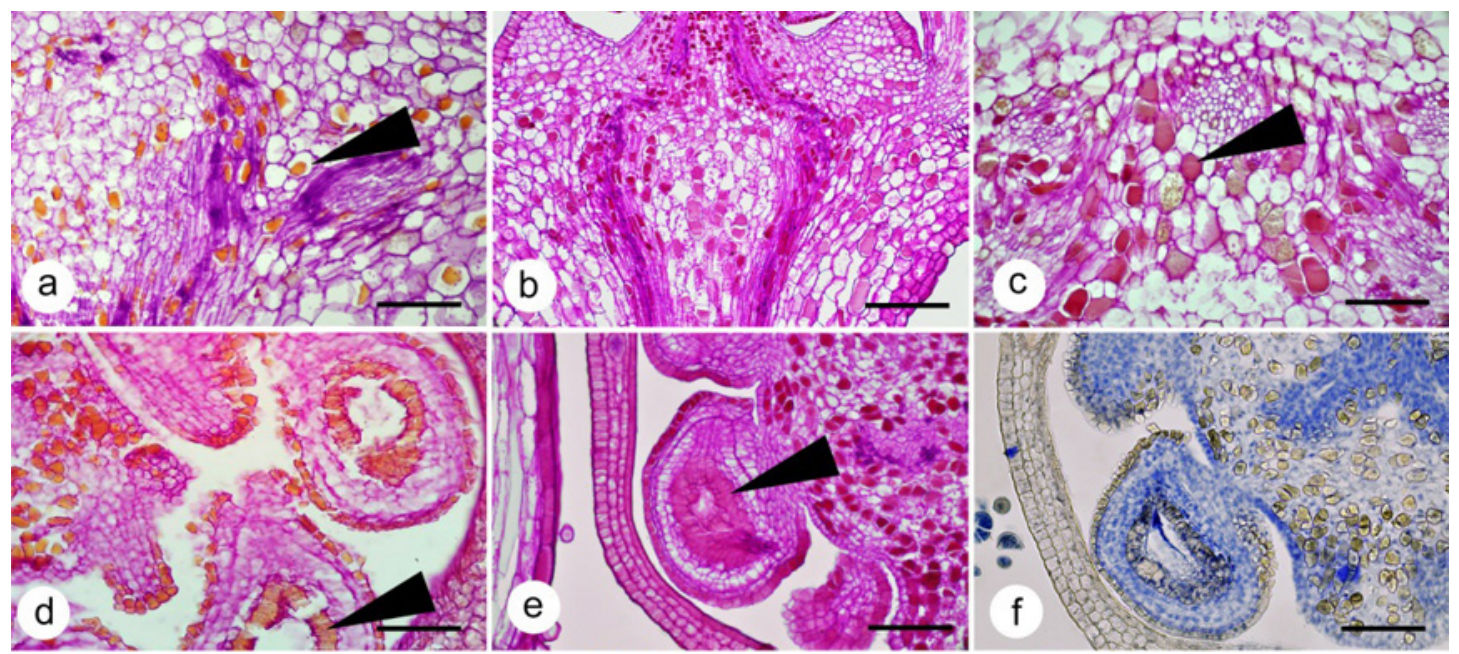

Рисунок 1a - f Локалізація білків і полісахаридів у клітинах та тканинах генеративних органів Lysimachia nummularia L.

a, d - локалізація полісахаридів та поліфенолів у стінках зав'язі та тканинах насіннєвих зачатків після ферментативного гідролізу пектинових речовин; b, e - тканини без попереднього гідролізу; c - реакція ШЙК (Шифф-Йодна кислота) на виявлення полісахаридів після обробки тканинами геміцелюлози та ксиланази (стрілка вказує на ідіобласт); $\mathrm{f}$ - локалізація білка в тканинах насіннєвих зачатків

Figure 1a - f Localization of proteins and polysaccharides in the cells and tissues of Lysimachia nummularia L. generative organs

a, $d$ - localization of polysaccharides and polyphenols in ovary walls and ovule tissues after enzymatic hydrolysis of pectin substances; b, e - the same without prior hydrolysis; c - PAS reaction to detect polysaccharides after tissue treatment with hemicellulase and xylanase (arrow shows idioblast); $\mathrm{f}$ - localization of protein in ovule tissues 

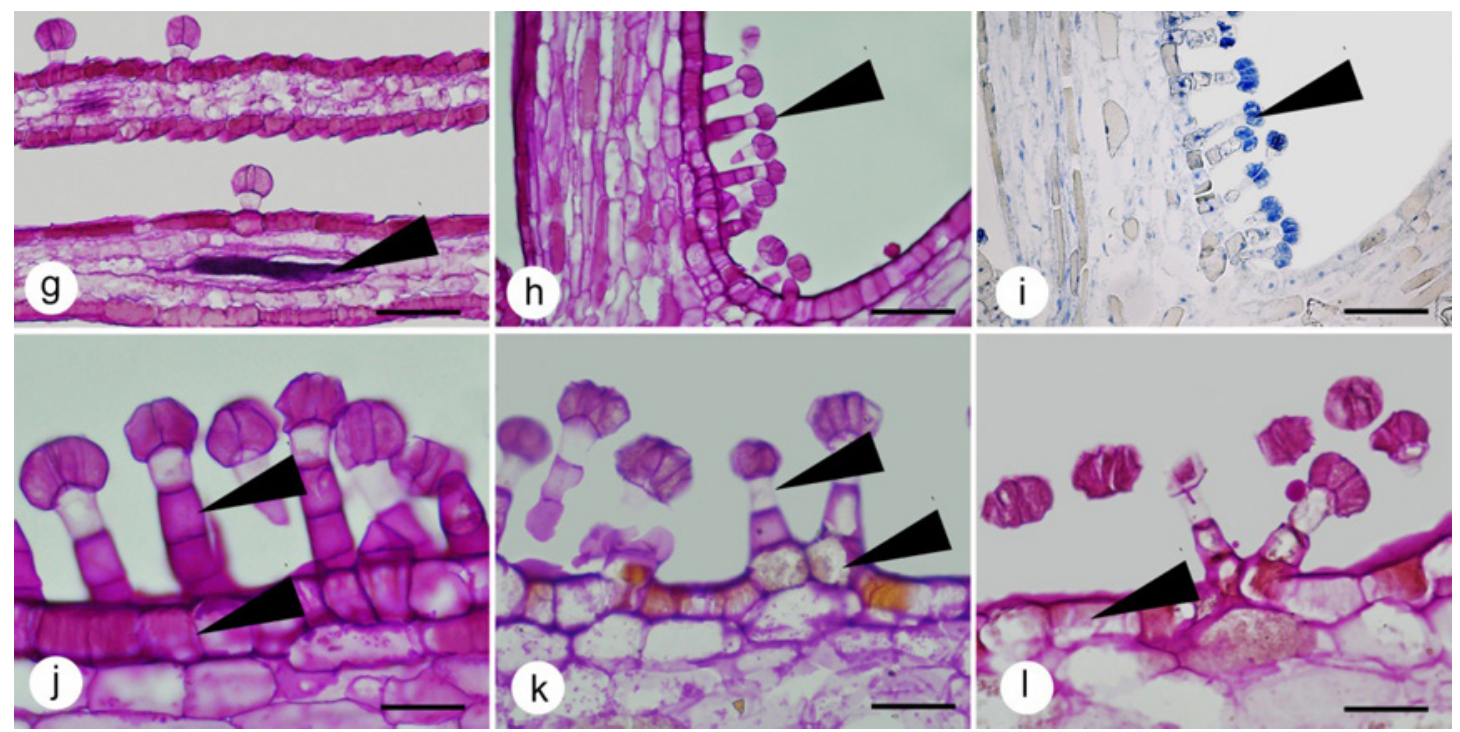

Рисунок $\mathbf{1 g}$ - I Локалізація білків і полісахаридів у клітинах та тканинах генеративних органів Lysimachia nummularia L.

$\mathrm{g}$ - полісахариди в секреторному вмістилищі; $\mathrm{h}$ - розподіл полісахаридів у клітинах секреторних трихом; i - локалізація білка в секреторних клітинах; j - накопичення полісахаридів у епідермісі, середніх та базальних клітинах ніжок трихом; k - реакція на полісахариди після ферментативного гідролізу пектинових речовин; I - реакція на полісахариди після ферментативного гідролізу тканин ксиланазою та геміцелюлазою (реакція Шифф-йодна кислота - ШЙК); a, c, d, j, h, i - bar = $100 \mu \mathrm{m} ; \mathrm{b}, \mathrm{e}, \mathrm{f}-\mathrm{bar}=200 \mu \mathrm{m}$; j, k, I - bar $=40 \mu \mathrm{m}$

Figure 19-I Localization of proteins and polysaccharides in the cells and tissues of Lysimachia nummularia L. generative organs

$\mathrm{g}$ - polysaccharides in the secretory receptacle; $\mathrm{h}$ - distribution of polysaccharides in the secretory, stalk and basal cells of glands; $i$ - localization of protein in secretory cells; $j$ - accumulation of polysaccharides in the epidermis, stalk and basal cells; $\mathrm{k}$ - reaction on polysaccharides after enzymatic hydrolysis of pectin; I reaction on polysaccharides after enzymatic hydrolysis of xylanase and hemicellulase (periodicacid-Schiff PAS reaction); a, c, d, j, h, i - bar $=100 \mu \mathrm{m} ; \mathrm{b}, \mathrm{e}, \mathrm{f}-\mathrm{bar}=200 \mu \mathrm{m} ; \mathrm{j}, \mathrm{k}, \mathrm{I}-\mathrm{bar}=40 \mu \mathrm{m}$

У головчастих трихомах Lysimachia nummularia нами також виявлено значні відкладення полісахаридів. У протопластах клітин-ніжок визначено пектини і геміцелюлози. Втім існує певна просторова нерівномірність їх розподілу у клітинах трихом. Полісахариди зосереджені у 1-й і 2-й базальних клітинах ніжок та майже повністю відсутні у клітині, що знаходиться під головкою (Figure 1, j, h). Важливим $\epsilon$ те, що її клітинні стінки дуже тонкі й майже повністю утворені пектиновими речовинами з незначним відкладенням целюлози і ксиланів (Figure 1, j, k). Це створює передумови для легкого відламування головки разом із секреторним наповненням саме в цій частині трихом навіть за умов незначних механічних навантажень. У результаті зменшується можливість витікання, окиснювання і полімеризації біологічно активних сполук через передчасне ушкодження секреторної головки. До складу епітелію секреторних головок Lysimachia nummularia також входять пектини і зв'язуючі глікани. Втім їх частка складає приблизно половину від загального пулу полісахаридів, решта яких нами не визначена. Отже, бджоли при збиранні голівок залозистих трихом отримують значну кількість летких сполук, жирних кислот, терпенів і флавоноїдів, а також полісахаридів, що в значній кількості містяться в секреті і можуть виконувати роль полімерної матриці при облицюванні бджолами комірок у гніздах. Визначена структурна особливість розподілу конституційних полісахаридів пояснює механічні властивості клітинних стінок і може 
розглядатись як коеволюційне пристосування для можливості ефективного збору рослинної олії бджолами роду Macropis. Отже, як справедливо відзначав ще В.В. Попов (1958), бджоли цього роду спряжено еволюціонували з рослинами роду Lysimachia.

\section{Висновки}

У переважній більшості ідіобластів поліфенольні сполуки оточені полісахаридними капсулами на основі пектинів, ксиланів і геміцелюлоз, які зменшують ймовірність автоінтоксикації клітин через негативний вплив продуктів окиснювання фенолів. Специфічне відкладання і розподіл полісахаридів у клітинних стінках і протопластах ідіобластів, клітин епідермісу і головчастих трихом за наявністю відповідних гідролаз створює передумови для їх мобільного перетворення на оліго-, ди- і моносахариди, що забезпечує тканини необхідними для росту і розвитку вуглеводами. Тонкі пектинові стінки середніх клітин ніжки трихоми легко рвуться, і відокремлення голівок відбувається без ушкодження клітин секреторного епітелію. Значне накопичення полісахаридів в клітинах секреторного епітелію може розглядатись як основа для створення полімерної плівки з бактерицидними і фунгіцидними складовими, які використовують бджоли при облицюванні комірок гнізд.

\section{Література}

Buchmann, S. 1987. The ecology of oil flowers and their bees. Annual Review of Ecology and Systematics, vol. 18, p. 343-369. ISSN 0066-4162.

Cane, J., Eickwort, G., Wesley, F., Spielholz, J. 1983. Foraging, grooming and mate-seeking behaviors of Macropis nuda (Hymenoptera, melittidae) and use of Lysimachia ciliata (Primulaceae) oils in larval provisions and cell linings. The American Midland Naturalist, vol. 110, no. 2, p. 257-264. DOI: $10.2307 / 2425267$

Pellicciari, C., Biggiogera, M. 2017. Histochemistry of single molecules. Methods and Protocols. Humana Press, p. 313-337. ISBN 978-1-4939-6787-2.

Podolak, I., Koczurkiewicz, P., Michalik, M., Galanty, A., Zajdel, P., Janeczko, Z. 2013. A new cytotoxic triterpene saponin from Lysimachia nummularia L. Carbohydrate Research, vol. 375, p. 16-20. ISSN 0008-6215.

Toth, A., Riethmüller, E., Alberti, A., Vegh, K., Kery, A. 2012. Comparative phytochemical screening of phenoloids in Lysimachia species. Eur. Chem. Bull., vol. 1, no. 1-2, p. 27-30. ISSN 2063-5346.

Демид, А.Є. 2014. Компонентний склад ефірної олії вербозілля лучного (Lysimachia nummularia L.). Медична хімія, т. 16, № 1, с. 58-61. ISSN 1681-2557.

Попов, В.В. 1958. Особенности сопряженной эволюции Macropis, Epeoloides (Hymenoptera, Apoidea) и Lysimachia (Primulaceae). Энтомологическое обозрение, т. 37, вып. 3, с. 499-519.

Радченко, В.Г., Песенко, Ю.А. 1994. Биология пчел (Нymenoptera, Аpoidea). Санкт-Петербург: Зоологический институт РАН. 350 с.

Фурст, Г.Г. 1979. Методы анатомо-гистохимического исследования растительных тканей. Наука, c. $40-65$. 